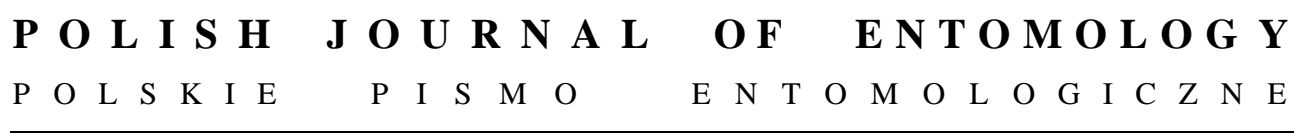

VOL. 85: $177-180$

Lublin

30 June 2016

DOI: 10.1515/pjen-2016-0009

\title{
Charles D. MICHENER, world-famous entomologist and bee expert, has passed on
}

\author{
JÓZEF BANASZAK \\ Department of Ecology, Institute of Biology and Environmental Protection, Kazimierz \\ Wielki University, Ossolińskich Av. 12, 85-093 Bydgoszcz, Poland
}

Charles Duncan MiCHENER, professor emeritus of entomology, taxonomy and ecology, passed away on 1 November 2015 at the age of 97 . He was a world authority on the natural history, classification and evolution of the 20000 species of bees. He was regarded as the 'patriarch' of bee research.

MichENER was born in Pasadena, California. His parents were amateur ornithologists, who taught young Charles and encouraged him to start observing nature. Aged just ten years, he made detailed watercolours of 120 flowers found in his neighbourhood. Also at an early age he began observing and collecting insects. He accompanied on their field trips some outstanding and renowned entomologists, such as T.D.A. COCKERELL and P.H. TIMBERLAKE, and visited their laboratories. He completed his first academic work at the age of 16, based on observations that he had begun when he was just 12 . After completing his studies, while working as a laboratory instructor, he married the student Mary HASTINGS. Their marriage lasted 69 years.

Just two years after gaining his first degree, Charles Michener wrote a doctoral dissertation, which he completed in 1941. Based on that work, his paper "Comparative external morphology, phylogeny, and a classification of the bees (Hymenoptera)" was published in 1944 in the Bulletin of the American Museum of Natural History (82: 151326). With that work began the "MiCHENER era" in bee research. In 1942-1948 he was an Assistant Curator of the Lepidoptera collection at the American Museum of Natural History in New York. He also worked for the United States Army in 1943-1946, researching the biology of ticks and mites and verifying his findings in Panama. In 1948 he moved to the University of Kansas, becoming Associate Professor in the Department of Entomology.

\footnotetext{
*Corresponding author: lednica@ukw.edu.pl
} 


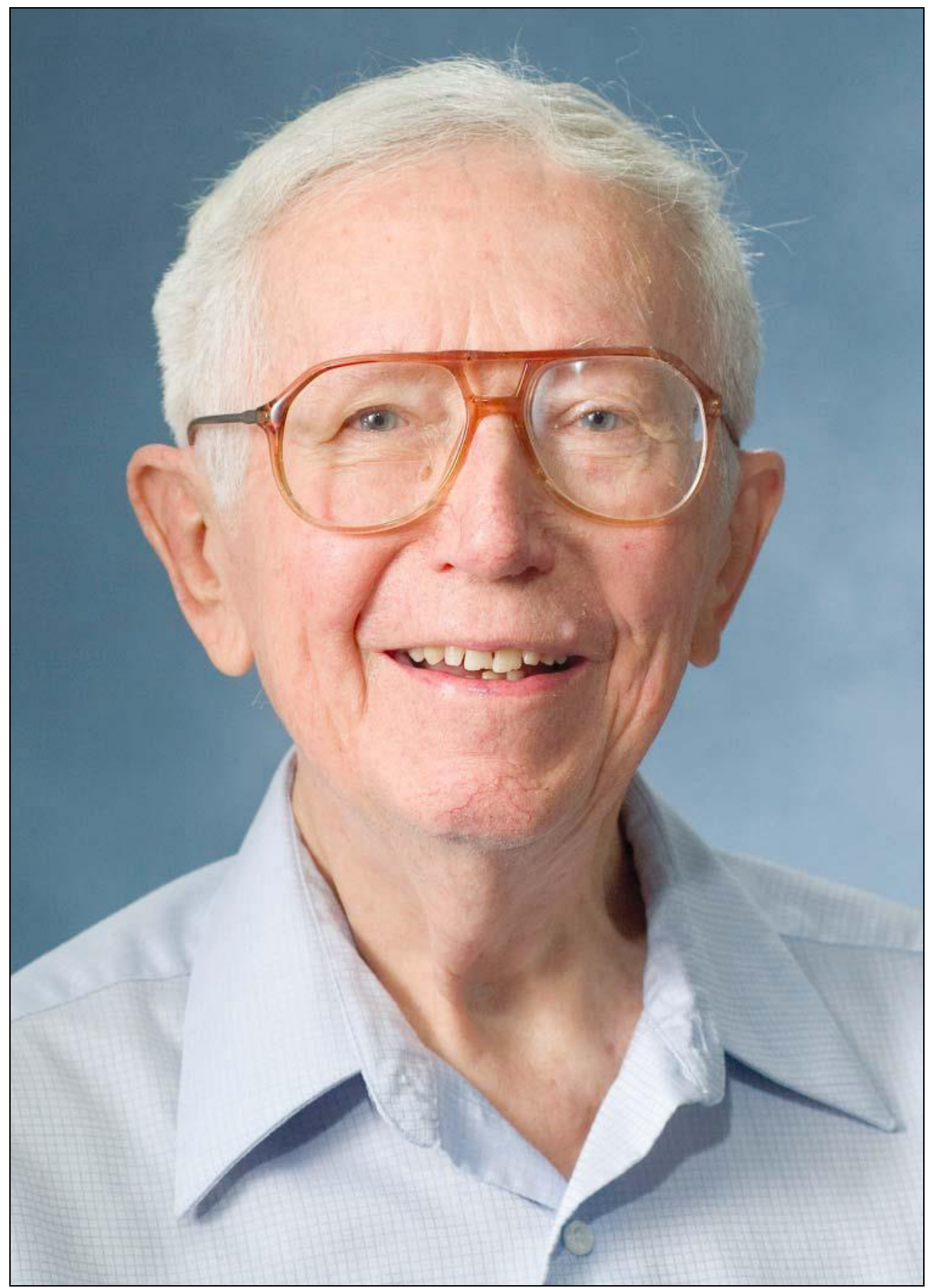

Professor Charles D. MichENER (1918-2015) 
While working full-time at Kansas, doing research, teaching, and publishing further work, MICHENER also undertook numerous foreign expeditions to carry out field studies of the bee fauna. Taking advantage of a Guggenheim Fellowship in 1955, he took his whole family to Brazil for a year. Next, a Fulbright Award in 1957 enabled him to go to Australia for a year, again with his family, to carry out more field studies.

A second Guggenheim Fellowship in 1966 enabled MichENER (known to most people simply as Mich), together with Mary and their two younger children, to spend 14 months in Africa in order to collect bees, making a journey of almost 3000 miles from South Africa to Uganda. On shorter trips, MiCHENER collected bees and made notes together with his colleagues in Mexico, Costa Rica, Panama, Peru, French Guiana, New Guinea, Fiji, China, and Thailand, as well as in the United States and Canada.

In 1974 MiCHENER published another of his many original and extensive works, "The Social Behavior of the Bees: a Comparative Study" (Cambridge, MA, Harvard University Press, $404 \mathrm{pp}$.), containing a synthesis of the social development of bees. Alongside the works of E.O. WILSON, it represents a revolution in biological thinking, giving rise to what is known as sociobiology.

MICHENER officially retired from teaching at the University of Kansas in 1989, although he continued to be active in research. The crowning of his career came with his vast life's work entitled "The Bees of the World" (2000). This book contains nearly 1000 pages and has illustrations of 16000 species. MICHENER published a second extended edition in 2007, when he was aged 89. In total, he published 514 works, and during his 80-year career he gave names to 618 previously unrecognized species, while 92 species were named after him.

This great scientist also has a Polish connection. I had the pleasure and honour of meeting Professor MICHENER in person. We met twice at conferences, in London (1995) and in Iguaçu, Brazil (2000), where we discussed topics related to bees. I also exchanged correspondence and publications with him. He reviewed two monographs of which I was a co-author: "Andreninae of the Central and Eastern Palaearctic. Part 1" (2005) and "Andreninae of the Central and Eastern Palaearctic. Part 2" (2008), published by the Polish Entomological Society in the Polish Entomological Monographs series. My greatest satisfaction, however, came when I was a young scientist, on seeing the results of my master's thesis cited in Professor MichENER's important work of 1979, "Biogeography of the Bees". Describing the variation among bees in different parts of the world, he took into account the first list of species of bees found in Poznań and its environs, published in Polish in 1973 in a local journal entitled Badania Fizjograficzne nad Polska Zachodnia (Physiographic Studies of Western Poland). To a young scientist it felt like a real success to be distinguished in this way. 


\section{REFERENCES}

MicheneR C.D. 2007. The Professional Development of an Entomologist. Annual Review of Entomology 52: 1-15.

SHEPHERD S. 2015. Charles MichENER, 'patriarch' of bee research, dies at 97. Lawrence Journal World. Internet: http://www2.ljworld.com/news/2015/nov/02/patriarch-bee-research-dies-97 [accessed 2015-11-02]

Entomological Society of America. 2015. Charles D. MiCHENER, ESA Fellow (1944). Internet: http://www.entsoc.org/fellows/michener [accessed 2015-03]

Lawrence Journal World. 2015. Charles D. MichENER. Obituary. Internet: http://obituaries.ljworld. com/obituaries/ljworld/obituary.aspx?pid=176327143 [accessed 2015-11-04]

Wikipedia. 2015. Charles Duncan MiCHENER. Internet: https://en.wikipedia.org/wiki/Charles_Duncan_ Michener [accessed 2015-12-14]

Received: 28 January 2016

Accepted: 30 January 2016 